\title{
Resolution of the Varietal Relationship within the Species Pichia opuntiae and Establishment of a New Species, Pichia thermotolerans comb. nov.
}

\author{
D. L. HOLZSCHU, $\dagger$ H. J. PHAFF, ${ }^{1 *}$ JOANNE TREDICK, ${ }^{1}$ AND DENNIS HEDGECOCK ${ }^{2}$ \\ Department of Food Science and Technology, University of California, Davis, California 95616, ${ }^{1}$ and Bodega Marine \\ Laboratory, University of California, Bodega Bay, California $94923^{2}$
}

\begin{abstract}
The varietal relationship within the species Pichia opuntiae was determined by a study of deoxyribonucleic acid relatedness and by a comparison of the electrophoretic mobilities of 12 metabolic enzymes. The nuclear genomes of $P$. opuntiae var. opuntiae and $P$. opuntiae var. thermotolerans showed about $28 \%$ relative binding to hydroxylapatite in intervarietal deoxyribonucleic acid reassociation experiments, and the allozymes encoded by eight loci were different in the two taxa. Based on these molecular criteria, as well as allopatry, different host plants, and weak sexual interaction, $P$. opuntiae var. thermotolerans is raised to the rank of species as Pichia thermotolerans (Starmer et al.) Holzschu et al. comb. nov.
\end{abstract}

Starmer et al. (20) described a new heterothallic cactusspecific yeast which they named Pichia opuntiae. Two varieties were designated based on differences in physiological properties, habitat, and geographic distribution. $P$. opuntiae var. opuntiae strains have been found only in necrotic tissue of Opuntia inermis (tribe Opuntiaeae, subtribe Opuntiinae) in Australia. This variety has a maximum temperature for growth of 30 to $33^{\circ} \mathrm{C}$, and assimilates citric acid strongly, and cellobiose utilization is latent, weak, or negative. $P$. opuntiae var. thermotolerans is associated with rotting tissue of several species of columnar cacti (tribe Pachycereeae, subtribe Pachycereinae) in a number of locations in the North American Sonoran Desert. It grows well at $37^{\circ} \mathrm{C}$ (but not at $39^{\circ} \mathrm{C}$ ) and assimilates cellobiose strongly but not citric acid. All other assimilation reactions of carbon compounds are the same. The reasons for considering these two taxa as varieties of a single species were the virtually identical guanine-plus-cytosine contents of their nuclear deoxyribonucleic acids (DNAs) and the observation that intervarietal matings of haploid heterothallic cells of opposite mating types produced a moderate number of zygotes, although extremely few asci were produced. In addition, the morphological properties of these varieties are similar, and the difference in physiological properties is small and may be based on a difference in only a few genes (15). However, there is a significant difference in sexual reproduction; haploid $P$. opuntiae var. opuntiae strains of opposite mating types conjugate well, and numerous viable spores are produced, whereas mating types of $P$. opuntiae var. thermotolerans conjugate infrequently and asci are therefore extremely rare. Presumably because of the strong mating ability of $P$. opuntiae var. opuntiae, intervarietal matings produce more zygotes than intravarietal matings of $\boldsymbol{P}$. opuntiae var. thermotolerans. Starmer et al. (18) suggested that the two varieties of $P$. opuntiae could represent the final stages in the speciation process. In this study we conducted DNA-DNA hybridization experiments and compared the electrophoretic mobilities of a number of key metabolic

\footnotetext{
* Corresponding author.

$\dagger$ Present address: Department of Radiation Biology and Biophysics, The University of Rochester Medical Center, Rochester, NY 14642 .
}

enzymes. Our results suggest that $P$. opuntiae var. thermotolerans should be raised to the rank of species.

\section{MATERIALS AND METHODS}

Strains. Yeast strains were obtained from the yeast culture collection of the Department of Food Science and Technology, University of California, Davis. The strains studied included all of those listed in the original taxonomic description of $P$. opuntiae (20), as well as a number of more recently isolated strains (Table 1 ).

Purification of DNA, base composition determination, and procedure for reassociation. DNA extraction and purification were carried out by using the methods described by Price et al. (15), except the purified DNA was concentrated by electrophoresis in a concentrator (ISCO, Lincoln, Nebr.) and the reference DNA was labeled with ${ }^{125} \mathrm{I}$ as described by Holzschu et al. (10). The guanine-plus-cytosine contents of the nuclear DNAs were calculated from buoyant density values in cesium chloride gradients established in a Spinco model $\mathrm{E}$ analytical ultracentrifuge equipped with photographic optics $(16,22)$ and were based on three separate

TABLE 1. Localities and sources of isolates of $P$. opuntiae var. thermotolerans which were not included in the original taxonomic description

\begin{tabular}{|c|c|c|}
\hline $\operatorname{Strain}(\mathrm{s})^{a}$ & $\begin{array}{l}\text { Geographic area of } \\
\text { isolation }\end{array}$ & Source \\
\hline $79-251,79-253$ & Tucson, Ariz. & $\begin{array}{l}\text { Carnegiea gigantea } \\
\text { (saguaro) }^{b}\end{array}$ \\
\hline $80-203$ & $\begin{array}{l}\text { El Arenoso, Baja } \\
\text { California Norte, } \\
\text { Mexico }\end{array}$ & $\begin{array}{l}\text { Pachycereus pringlei } \\
\text { (cardon) }\end{array}$ \\
\hline $80-204,80-205$ & $\begin{array}{l}\text { El Arenoso, Baja } \\
\text { California Norte, } \\
\text { Mexico }\end{array}$ & $\begin{array}{l}\text { Drosophila larvae from } \\
\text { Pachycereus pringlei } \\
\text { (cardon) }\end{array}$ \\
\hline $80-206,80-207$ & $\begin{array}{l}\text { Punta Prieta, Baja } \\
\text { California Sur, } \\
\text { Mexico }\end{array}$ & $\begin{array}{l}\text { Pachycereus pringlei } \\
\text { (cardon) }\end{array}$ \\
\hline
\end{tabular}

a Culture Collection, Department of Food Science and Technology, University of California, Davis.

$b$ The common names of the cacti are given in parentheses. 
TABLE 2. DNA base compositions and sources of yeast strains used in DNA-DNA hybridization experiments

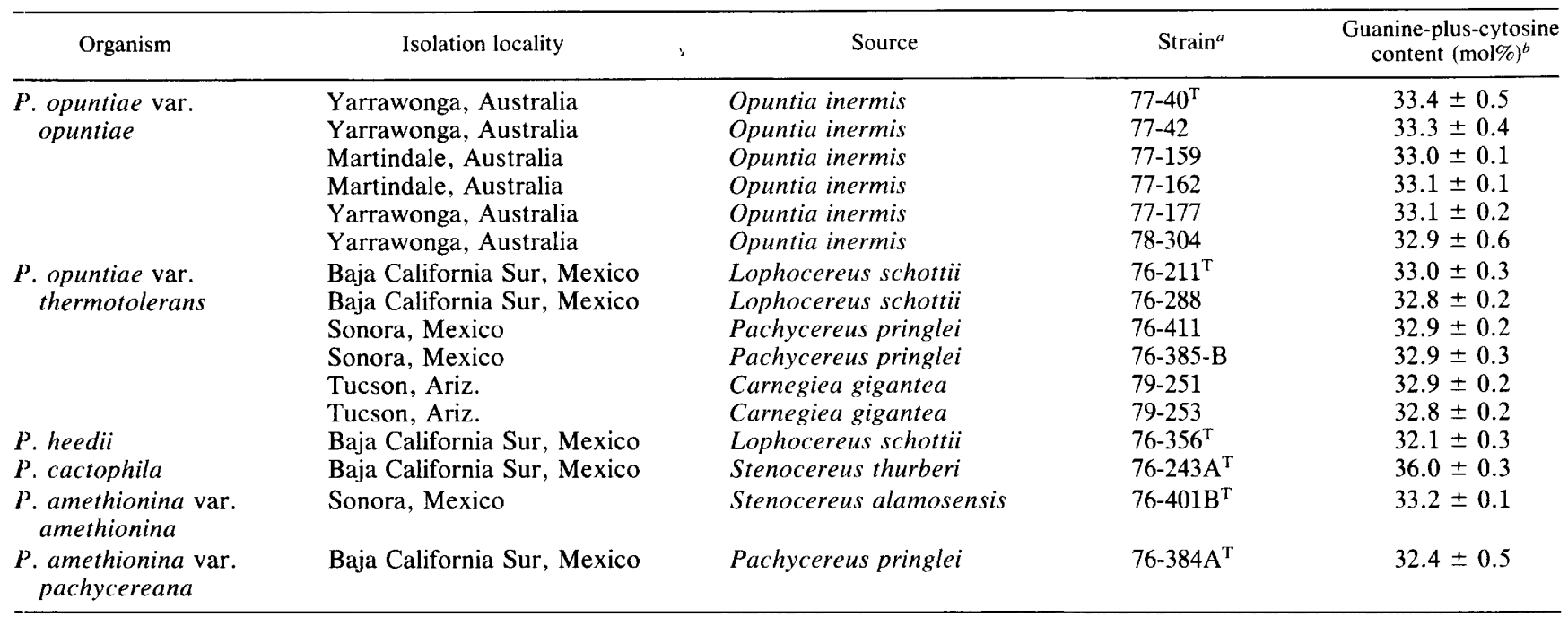

${ }^{a}$ Culture collection, Department of Food Science and Technology, University of California, Davis.

${ }^{b}$ Mean \pm standard deviation, based on three independent determinations.

determinations. DNA from Micrococcus luteus strain 2039 (International Collection of Phytopathogenic Bacteria, Department of Bacteriology, University of California, Davis), with a buoyant density of $1.7310 \mathrm{~g} / \mathrm{ml}$, was used as a reference. The buoyant density of the $M$. luteus DNA was derived from a comparison with plasmid-free Escherichia coli K-12 DNA, the buoyant density of which was taken to be $1.7100 \mathrm{~g} / \mathrm{ml}$. Denaturation of DNA, incubation for reassociation, and analysis of the renaturation kinetics, reannealing reactions, and quantitation of single- and doublestranded DNAs were carried out according to the protocol of Price et al. (15). Samples were counted with a gamma ray counter ( $90 \%$ efficiency).

Allozyme analysis. For allozyme analyses, yeast cells were transferred from a stock slant to $5 \mathrm{ml}$ of yeast autolysate $(0.5 \%)$ supplemented with $5 \%$ glucose and incubated for 20 to $24 \mathrm{~h}$ at $30^{\circ} \mathrm{C}$ on a Rollor drum. Each sample was then used as an inoculum for $100 \mathrm{ml}$ of the same medium in a $250-\mathrm{ml}$ flask, which was incubated on a rotary shaker at $180 \mathrm{rpm}$ for 20 to $24 \mathrm{~h}$ at $30^{\circ} \mathrm{C}$. The cells were harvested by centrifugation, suspended in approximately $15 \mathrm{ml}$ of $0.1 \mathrm{M}$ tris(hydroxymethyl)aminomethane hydrochloride buffer $(\mathrm{pH}$ 7.4), and disrupted in a Bronwill cell homogenizer containing glass beads (diameter, $0.5 \mathrm{~mm}$ ) for $3 \mathrm{~min}$ with $\mathrm{CO}_{2}$ cooling. After cell breakage, a 1- to 2-ml portion of each suspension was removed with a Pasteur pipette, placed in a single well of a plastic tray ( 24 samples per tray), covered, and frozen immediately. The samples were stored at $-20^{\circ} \mathrm{C}$ for not more than 3 days before transfer to $-80^{\circ} \mathrm{C}$.

The protocols used for starch gel preparation, buffer preparation, electrophoresis, gel cutting, and staining have been described by Ayala et al. (4), Tracey et al. (23), Harris and Hopkinson (8), and Shaw and Prasad (17). The enzymes studied were resolved by using the following four buffer systems (see references $4,8,17$, and 23 for buffer strengths): discontinuous tris(hydroxymethyl)aminomethane-citrate electrode buffer $(\mathrm{pH} 8.65)$ and borate $(\mathrm{NaOH})$ gel buffer $(\mathrm{pH}$ 8.1) (buffer system A); continuous tris(hydroxymethyl)aminomethane-borate-ethylenediaminetetraacetate ( $\mathrm{pH}$ 9.1) electrode and gel buffer (buffer system B); continuous tris(hydroxymethyl)aminomethane-citrateethylenediaminetetraacetate electrode buffer ( $\mathrm{pH} 7.0)$ and, for gel buffer, a 15-fold dilution of the electrode buffer (buffer system $\mathrm{C}$ ); and continuous phosphate-citrate ( $\mathrm{pH} 7.0$ ) electrode and gel buffer (buffer system D). The banding patterns of the following enzymes were resolved by specific staining after horizontal electrophoresis in the buffer system indicated in parentheses: alcohol dehydrogenase (buffer system B); fumarase (buffer system C); glucose-6-phosphate dehydrogenase (buffer system A); hexokinase (buffer system B); leucine aminopeptidase (buffer system A); malate dehydrogenase (buffer system B); glucose phosphate isomerase (buffer system D); phosphoglucomutase (buffer system C); tetrazolium reductase (buffer system $\mathrm{B}$ ); and triose phosphate isomerase (buffer system B). Activity stains (4) were prepared 30 to $60 \mathrm{~min}$ before use, and horizontal slices of the starch gels were incubated in the staining solutions in the dark until the indicator dyes appeared. Gels were fixed and stored as described by Ayala et al. (4). A total of 26 samples were run in each starch gel ( 19.5 by 17.5 by $1 \mathrm{~cm})$ by placing wicks soaked in cell extracts approximately $0.3 \mathrm{~cm}$ apart. The genetic basis of zymograms was inferred from their similarity to zymograms of other species whose Mendelian inheritance had been analyzed. In this study, however, we referred to the allozyme bands as electromorphs rather than as alleles because the genetic basis of the bands is incompletely known in P. opuntiae and Pichia thermotolerans. The nomenclature used for the gene-enzyme systems follows that of Ayala et al. (4), in which the loci encoding the enzymes are designated by italicized enzyme abbreviations.

The type strain of Pichia heedii Phaff et al. (strain 76-356) was used as the reference strain for determining the relative mobilities of the corresponding enzymes from other yeasts. The mobility for each gene-enzyme system detected in strain $76-356^{\mathrm{T}}$ ( $\mathrm{T}=$ type strain), was arbitrarily assigned a value of 100 ; designations for allozymes from other strains were obtained by adding or subtracting the number of millimeters separating the corresponding band from the band at a value of 100 (23). Controls to determine the identities of electromorphs were included in every gel by including the standard strain, 76-356 ${ }^{\mathrm{T}}$, and by cross-controlling each set of gels. In addition, representatives of each species were run side by side on a series of gels so that direct comparisons of enzyme mobilities could be made. 
TABLE 3. Reassociation of ${ }^{125}$ I-labeled nuclear DNA isolated from $P$. opuntiae var. opuntiae $77-40^{\mathrm{T}}$ with DNAs of other cactophilic yeast strains ${ }^{a}$

\begin{tabular}{|c|c|c|}
\hline Organism or tịssue & Strain & $\begin{array}{l}\text { Level of Relative } \\
\text { binding }(\%)^{b}\end{array}$ \\
\hline P. opuntiae var. opuntiae & $77-40^{\mathrm{T}}$ & 100 \\
\hline$P$. opuntiae var. opuntiae & $77-42$ & $97.4 \pm 1.4$ \\
\hline P. opuntiae var. opuntiae & $77-159$ & $100.3 \pm 0.3$ \\
\hline P. opuntiae var. opuntiae & $77-162$ & $95.3 \pm 0.6$ \\
\hline P. opuntiae var. opuntiae & $77-177$ & $94.1 \pm 1.0$ \\
\hline$P$. opuntiae var. opuntiae & $78-304$ & $93.6 \pm 0.7$ \\
\hline P. opuntiae var. thermotolerans & $76-211^{\mathrm{T}}$ & $\begin{array}{l}28.1 \pm 0.3 \\
(26.4 \pm 2.1)^{c}\end{array}$ \\
\hline P. opuntiae var, thermotolerans & 76-385B & $\begin{array}{c}28.8 \pm 0.7 \\
(26.7 \pm 1.0)\end{array}$ \\
\hline P. amethionina var. amethionina & $76-401 B^{T}$ & $6.1 \pm 0.1$ \\
\hline P. amethionina var. pachycereana & $76-384 A^{T}$ & $6.9 \pm 0.2$ \\
\hline P. heedii & $76-356^{\mathrm{T}}$ & $2.2 \pm 0.3$ \\
\hline P. cactophila & $76-243 A^{T}$ & $2.2 \pm 0.3$ \\
\hline Calf thymus DNA & & $1.0 \pm 1.0$ \\
\hline
\end{tabular}

a ${ }^{125}$ I-labeled DNA $(0.2 \mu \mathrm{g})$ and unlabeled DNA $(200 \mu \mathrm{g})$ were incubated at $61.2^{\circ} \mathrm{C}$ for $25 \mathrm{~h}$ in $0.5 \mathrm{ml}$ of $280 \mathrm{mM}$ phosphate buffer.

${ }^{b}$ Mean \pm standard deviation. Average of triplicate tests, corrected for zero-time binding $(0.5 \%)$ and for self reassociation of labeled DNA (2.0 \pm $0.8 \%)(15)$.

c The data in parentheses are the results from an independent experiment done under comparable conditions (zero-time binding, $0.6 \%$; selfreassociation, $3.8 \pm 0.5 \%$ ).

\section{RESULTS}

DNA hybridization experiments. The guanine-pluscytosine contents of the nuclear DNAs of the yeast strains included in this study are shown in Table 2 . A number of representative strains were examined by DNA-DNA reassociation for intravarietal homogeneity, intervarietal affinity, and interspecific similarity.

The results of experiments in which we compared the base sequence similarity of $P$. opuntiae var. opuntiae and $P$. opuntiae var. thermotolerans are shown in Tables 3 and 4 . The cactus-specific species $P$. heedii, Pichia amethionina, and $P$ ichia cactophila are not closely related to $P$. opuntiae var. opuntiae or $P$. opuntiae var. thermotolerans. The two varieties of $P$. opuntiae are well-defined taxa, as indicated by

TABLE 4. Reassociation of ${ }^{125}$ I-labeled nuclear DNA isolated from $P$. opuntiae var. thermotolerans $76-211^{\mathrm{T}}$ with DNAs of other cactophilic yeast strains ${ }^{a}$

\begin{tabular}{llc}
\hline \multicolumn{1}{c}{ Organism or tissue } & Strain & $\begin{array}{c}\text { Level of } \\
\text { relative } \\
\text { binding }(\%)^{b}\end{array}$ \\
\hline$P$. opuntiae var. thermotolerans & $76-211^{\mathrm{T}}$ & 100 \\
$P$. opuntiae var. thermotolerans & $76-411$ & $99.0 \pm 2.5$ \\
$P$. opuntiae var. thermotolerans & $76-288$ & $99.7 \pm 0.7$ \\
$P$. opuntiae var. thermotolerans & $79-251$ & $95.5 \pm 1.7$ \\
$P$. opuntiae var. thermotolerans & $79-253$ & $95.3 \pm 2.6$ \\
$P$. opuntiae var. thermotolerans & $76-385 \mathrm{~B}$ & $90.0 \pm 0.7$ \\
$P$. opuntiae var. apuntiae & $77-40^{\mathrm{T}}$ & $34.0 \pm 0.9$ \\
$P$. amethionina var. amethionina & $76-401 \mathrm{~B}^{\mathrm{T}}$ & $9.0 \pm 0.2$ \\
$P$. heedii & $76-356^{\mathrm{T}}$ & $9.7 \pm 1.0$ \\
$P$. cactophila & $76-243 \mathrm{~A}^{\mathrm{T}}$ & $9.1 \pm 1.5$ \\
Calf thymus DNA & & $1.6 \pm 0.9$ \\
\hline
\end{tabular}

a ${ }^{125}$ I-labeled DNA $(0.2 \mu \mathrm{g})$ and unlabeled DNA $(200 \mu \mathrm{g})$ were incubated at $61.2^{\circ} \mathrm{C}$ for $25 \mathrm{~h}$ in $0.5 \mathrm{ml}$ of $280 \mathrm{mM}$ phosphate buffer.

${ }^{b}$ Mean \pm standard deviation. Average of triplicate tests, corrected for zero-time binding $(1.0 \%)$ and for self-reassociation of labeled DNA $(5.0 \pm$ $0.3 \%)(15)$.
TABLE 5. Occurrence of electromorphs with frequencies of at least 0.05 in populations of $P$. opuntiae var. opuntiae and $P$. opuntiae var. thermotolerans

\begin{tabular}{|c|c|c|c|c|}
\hline \multirow[b]{2}{*}{$\operatorname{Locus}^{a}$} & \multirow{2}{*}{$\begin{array}{l}\text { No. of } \\
\text { haploid } \\
\text { strains } \\
\text { examined }\end{array}$} & \multirow[b]{2}{*}{$\begin{array}{l}\text { Electro- } \\
\text { morph(s) }\end{array}$} & \multicolumn{2}{|c|}{ Frequency in: } \\
\hline & & & $\begin{array}{l}P . \text { opuntiae } \\
\text { var. opuntiae }\end{array}$ & $\begin{array}{c}\text { P. opuntiae } \\
\text { var. } \\
\text { thermotolerans }\end{array}$ \\
\hline$A d h$ & 12 & 100 & $-^{c}$ & 1.00 \\
\hline Fum & 29 & 92 & 100 & 1.00 \\
\hline$T r$ & 29 & 104 & $\begin{array}{l}1.00 \\
1.00\end{array}$ & 1.00 \\
\hline G-6-pdh & 17 & 110 & 1.00 & - \\
\hline$H k-I$ & 29 & 99 & & 1.00 \\
\hline$H k-2$ & 29 & $\begin{array}{r}100 \\
85\end{array}$ & $\begin{array}{l}1.00 \\
1.00\end{array}$ & \\
\hline & & 96 & & 1.00 \\
\hline$H k-3$ & 29 & $\begin{array}{l}85 \\
87\end{array}$ & $\begin{array}{l}0.50 \\
0.50\end{array}$ & \\
\hline & & 96 & & 1.00 \\
\hline Lap & 29 & 96 & & 1.00 \\
\hline & & $\begin{array}{r}97 \\
100\end{array}$ & $\begin{array}{l}0.44 \\
0.56\end{array}$ & \\
\hline$M d h$ & 29 & 101 & & 1.00 \\
\hline & & 106 & 1.00 & \\
\hline$P g m$ & 29 & 128 & 0.94 & 1.00 \\
\hline Gpi & 29 & $\begin{array}{l}108 \\
110 \\
113\end{array}$ & 1.00 & $\begin{array}{l}0.08 \\
0.92\end{array}$ \\
\hline$T p i$ & 29 & $\begin{array}{l}102 \\
104 \\
113\end{array}$ & 1.00 & $\begin{array}{l}0.75 \\
0.25\end{array}$ \\
\hline
\end{tabular}

a The locus designations are for the following enzymes: Adh, alcohol dehydrogenase; Fum, fumarase; $T r$, tetrazolium reductase; $G-6-p d h$, glucose6-phosphate dehydrogenase; $H k-1$, hexokinase $1 ; H k-2$, hexokinase $2 ; H k-3$, hexokinase 3 ; Lap, leụcine aminopeptidase; $M d h$, malate dehydrogenase; $P g m$, phosphoglucomutase; Gpi, glucose phosphate isomerase; Tpi, triose phosphate isomerase.

${ }^{b}$ Electromorphs were designated in reference to the standard electromorphs from $P$. heedii $76-356^{\mathrm{T}}$, which were arbitrarily assigned values of 100 (23) (see text)

c _-, No data (band not resolved in the gel-buffer system used).

the high degree of DNA complementarity among the strains tested within the two varieties (more than $90 \%$ relative binding). The mean relative binding level when the two varieties were compared was $28.0 \pm 3.1 \%$, based on five pair-wise comparisons (including reverse experiments). The low level of base sequence similarity supports our proposal that the two varieties of $\boldsymbol{P}$. opuntiae should be divided into two separate but closely related species.

Allozyme analysis. $P$. opuntiae var. opuntiae and $P$. opuntiae var. thermotolerance were compared by allozyme analyses at 12 loci (Table 5). The allozyme pattern of $\boldsymbol{P}$. opuntiae var. thermotolerans was unique and was easily distinguished from that of $P$. opuntiae var. opuntiae. The allozymes encoded by the loci $F u m, H K-1, H K-2, H K-3$, $L a p, M d h, G p i$, and Tpi were different in the two taxa and thus allowed unequivocal identification of the proposed species. The experiments described here were undertaken to obtain additional measures of genetic diversity between the two varieties of $P$. opuntiae. The lack of interfertility between $P$. opuntiae var. opuntiae and $P$. opuntiae var. thermotolerans observed in our laboratory (a moderate number of zygotes are produced, but very few asci are observed) indicates that these two varieties have become genetically isolated, perhaps due to allopatry and different host plants. $P$. opuntiae var. opuntiae occurs in rots of $O$. 
inermis in Australia, and strains of this variety have not been isolated thus far from Opuntia species in Arizona and Texas (19) or on various Caribbean islands (H. J. Phaff and W. T. Starmer, unpublished data). On the other hand, $P$. opuntiae var. thermotolerans has been found only in columnar cacti of the North American Sonoran Desert. The molecular data presented here and the reproductive isolation $(7,14)$ of the two varieties lead us to propose that $P$. opuntiae var. ihermotolerans should be elevated to the rank of species as Pichia thermotolerans (Starmer et al.) Holzschu et al. comb. nov. (basionym, Pichia opuntiae var. thermotolerans Starmer et al. Int. J. Syst. Bacteriol. 29:161, 1979).

\section{DISCUSSION}

The experiments described above were undertaken to obtain additional measures of the genetic diversity between $P$. opuntiae and $\boldsymbol{P}$. thermotolerans. DNA-DNA complementarity values and allozyme analyses demonstrated that the two species are very different at the genetic level. The mean level of interspecific relative binding to hydroxylapatite of the reassociated DNAs of the two species was $28.0 \pm 3.1 \%$ based on five pair-wise comparisons. Actual DNA-DNA complementarity values are probably somewhat higher because in experiments with distantly related species selfrenaturation of the unlabeled DNA (driver DNA) occurs at a faster rate than the renaturation of the driver DNA with the heterologous labeled probe DNA. As a result, the driver DNA concentration is rapidly reduced in the reaction mixture, thereby preventing it from reannealing with the probe DNA. The renaturation kinetics of DNAs isolated from $P$. opuntiae $77-40^{\mathrm{T}}$ and $P$. thermotolerans $76-211^{\mathrm{T}}$ were followed by a $\mathrm{C}_{0} \mathrm{t}$ analysis in one experiment $\left(\mathrm{C}_{0} \mathrm{t}\right.$ is the initial nucleotide concentration in moles per liter $\times$ time in seconds [6]) and were compared with the homologous $P$. opuntiae $77-40^{\mathrm{T}}$ renaturation reaction (data not shown). The renaturation curve (6) of the heterologous reaction was shifted to the right of the homologous curve. The kinetics of renaturation are second order and depend on the concentration of driver DNA. The shift to the right by the heterologous reaction in comparison with the homologous reaction illustrates the point that the driver DNA was being depleted from the reaction, and therefore our complementarity values are lower than those that could theoretically be obtained. Nevertheless, the relatively low DNA complementarity value supports the species status of $P$. thermotolerans.

Another recently described heterothallic species, Pichia antillensis (21), appears to be more closely related to $P$. opuntiae than $P$. thermotolerans is. In reassociation experiments the DNA of $P$. antillensis showed about 55\% relative binding with $P$. opuntiae reference DNA, compared with the value of approximately $28 \%$ observed between $P$. opuntiae and $P$. thermotolerans. Despite the higher level of DNA complementarity, the mating types of $P$. antillensis showed no sexual interaction with those of $P$. opuntiae (21).

Similar to our results with $P$. opuntiae and $P$. thermotolerans, Kurtzman et al. (13) observed interspecific mating between Pichia amylophila and Pichia mississippiensis, but ascospores from the crosses were infertile. These two species exhibited about 25\% DNA relatedness. Similarly, Hansenula bimundalis and Hansenula americana (with about $21 \%$ DNA relatedness) showed poor conjugation, and ascospores were not produced (11). In contrast, Issatchenkia scutulata var. scutulata and I. scutulata var. exigua (with about 25\% DNA relatedness) showed good conjugation between appropriate mating types, and the zygotes produced a low percentage of viable spores (12). On the basis of spore viability, Kurtzman et al. retained these yeasts as varieties of $I$. scutulata (12). In matings between $P$. thermotolerans and $P$. opuntiae asci were so rare that spore viability could not be tested.

A study of the electrophoretic mobilities of 12 metabolic enzymes revealed that $P$. opuntiae and $P$. thermotolerans can be differentiated unequivocally by differences in the electrophoretic mobilities of eight enzymes. The allozyme patterns of fumarase, hexokinases 1,2 , and 3 , leucine aminopeptidase, malate dehydrogenase, glucosephosphate isomerase, and triose phosphate isomerase can be used in the formal descriptions of $P$. thermotolerans and $P$. opuntiae as additional criteria to differentiate the two sibling species, as was done previously by Holzschu et al. (9) in the differentiation of Pichia pseudocactophila from $P$. cactophila and by Baptist and Kurtzman (5) in separating Cryptococcus magnus and Cryptococcus heveanensis. A previous use of this technique to differentiate subspecies of Drosophila has been described by Ayala and co-workers $(1-3)$.

\section{ACKNOWLEDGMENTS}

This work was supported by Public Health Service grant GM-16370 from the National Institute of General Medical Sciences to H.J.P. and by grant 4803 from the Institute of Ecology, University of California, Davis, to D.H., H.J.P. and D.L.H.

\section{LITERATURE CITED}

1. Ayala, F. J. 1973. Two new subspecies of the Drosophila willistoni group (Diptera: Drosophilidae). Pan-Pac. Entomol. 49:273-279.

2. Ayala, F. J., and T. Dobzhansky. 1974. A new subspecies of Drosophila pseudoobscura (Diptera: Drosophilidae). Pan-Pac. Entomol. 50:211-219.

3. Ayala, F. J., and J. R. Powell. 1972. Allozymes as diagnostic characters of sibling species of Drosophila. Proc. Natl. Acad. Sci. U.S.A. 69:1094-1096.

4. Ayala, F. J., J. R. Powell, M. L. Tracey, C. A. Mourao, and S. Perez-Salas. 1972. Enzyme variability in the Drosophila willistoni group IV. Genetic variability in natural populations of Drosophila willistoni. Genetics 70:113-139.

5. Baptist, J. N., and C. P. Kurtzman. 1976. Comparative enzyme patterns in Cryptococcus laurentii and its taxonomic varieties. Mycologia 68:1195-1203.

6. Britten, R. J., and D. E. Kohne. 1968. Repeated sequences in DNA. Science 161:529-540.

7. Dobzhansky, T. 1976. Organismic and molecular aspects of species formation, p. 95-105. In F. J. Ayala (ed.), Molecular evolution. Sinauer Associates, Inc. Sunderland, Mass.

8. Harris, H., and D. A. Hopkinson. 1976. Handbook of enzyme electrophoresis in human genetics. American Elsevier Publishing Co., Inc., New York.

9. Holzschu, D. L., H. J. Phaff, J. Tredick, and D. Hedgecock. 1983. Pichia pseudocactophila, a new species of yeast occurring in necrotic tissue of columnar cacti in the North American Sonoran Desert. Can. J. Microbiol. 29:1314-1322.

10. Holzschu, D. L., H. L. Presley, M. Miranda, and H. J. Phaff. 1979. Identification of Candida lusitaniae as an opportunistic yeast in humans. J. Clin. Microbiol. 10:202-205.

11. Kurtzman, C. P. 1984. Resolution of varietal relationships within the species Hansenula anomala, Hansenula bimundalis, and Pichia nakazawae through comparisons of DNA relatedness. Mycotaxon 19:271-279.

12. Kurtzman, C. P., M. J. Smiley, and C. J. Johnson. 1980. Emendation of the genus Issatchenkia Kudriavzev and comparison of species by deoxyribonucleic acid reassociation, mating reaction, and ascospore ultrastructure. Int. J. Syst. Bacteriol. 30:503-513.

13. Kurtzman, C. P., M. J. Smiley, C. J. Johnson, L. J. Wickerham, and G. B. Fuson. 1980. Two new and closely related heterothal- 
lic species, Pichia amylophila and Pichia mississippiensis: characterization by hybridization and deoxyribonucleic acid reassociation. Int. J. Syst. Bacteriol. 30:208-216.

14. Phaff, H. J. 1980. The species concept in yeast: physiologic, morphologic, genetic, and ecological parameters, p. 635-643. In G. G. Stewart and I. Russell (ed.), Current developments in yeast research. Pergamon Press, Toronto.

15. Price, C. W., G. B. Fuson, and H. J. Phaff. 1978. Genome comparison in yeast systematics: delimitation of species within the genera Schwanniomyces, Saccharomyces, Debaryomyces, and Pichia. Microbiol. Rev. 42:161-193.

16. Schildkraut, C. L., J. Marmur, and P. Doty. 1962. Determination of the base composition of deoxyribonucleic acid from its buoyant density in $\mathrm{CsCl}$. J. Mol. Biol. 4:430-433.

17. Shaw, C. R., and R. Prasad. 1970. Starch gel electrophoresis of enzymes-a compilation of recipes. Biochem. Genet. 4:297-310.

18. Starmer, W. T., H. W. Kircher, and H. J. Phaff. 1980. Evolution and speciation of host plant-specific yeasts. Evolution
34:137-146.

19. Starmer, W. T., and H. J. Phaff. 1983. Analysis of the community structure of yeasts associated with the decaying stems of cactus. II. Opuntia species. Microb. Ecol. 9:247-259.

20. Starmer, W. T., H. J. Phaff, M. Miranda, M. W. Miller, and J. S. F. Barker. 1979. Pichia opuntiae, a new heterothallic species of yeast found in decaying cladodes of Opuntia inermis and in necrotic tissue of cereoid cacti. Int. J. Syst. Bacteriol. 29:159-167.

21. Starmer, W. T., H. J. Phaff, J. Tredick, M. Miranda, and V. Aberdeen. 1984. Pichia antillenis, a new species of yeast associated with necrotic stems of cactus in the Lesser Antilles. Int. J. Syst. Bacteriol. 34:350-354.

22. Szybalski, W. 1969. Use of cesium sulfate for equilibrium density gradient centrifugation. Methods Enzymol. 12:330-360.

23. Tracey, M. L., K. Nelson, D. Hedgecock, R. A. Schleser, and M. L. Pressick. 1975. Biochemical genetics of lobsters (Homarus): genetic variation and structure of American lobster populations. J. Fish. Res. Board Can. 33:1108-1119. 